Liberalism and Community 



\section{Liberalism and Community}

X

STEVEN KAUTZ

CORNELL UNIVERSITY PRESS • ITHACA \& LONDON 


\section{Copyright $\odot 1995$ by Cornell University}

All rights reserved. Except for brief quotations in a review, this book, or parts thereof, must not be reproduced in any form without permission in writing from the publisher. For information, address Cornell University Press, Sage House, 512 East State Street, Ithaca, New York 14850.

First published 1995 by Cornell University Press.

First printing, Cornell Paperbacks, 1997.

Printed in the United States of America

Cornell University Press strives to utilize environmentally responsible suppliers and materials to the fullest extent possible in the publishing of its books. Such materials include vegetable-based, low-VOC inks and acid-free papers that are also either recycled, totally chlorine-free, or partly composed of nonwood fibers.

\section{Library of Congress Cataloging-in-Publication Data}

\section{Kautz, Steven J.}

Liberalism and community / Steven Kautz. p. $\mathrm{cm}$.

Includes bibliographical references and index.

ISBN 0-8014-2979-X (alk. paper)

ISBN 0-8014-8481-2 (pbk. : alk. paper)

1. Liberalism. 2. Community. I. Title. HM276.K258 1995

$320.5^{\prime} 1-\mathrm{dc} 20$

$\begin{array}{lllllllllll}\text { Cloth printing } & 10 & 9 & 8 & 7 & 6 & 5 & 4 & 3 & 2 & 1\end{array}$

$\begin{array}{lllllllllll}\text { Paperback printing } & 10 & 9 & 8 & 7 & 6 & 5 & 4 & 3 & 2 & 1\end{array}$ 
To the memory of Allan Bloom 
